The Canadian Mineralogist

Vol. 42, pp. 423-437 (2004)

\title{
VARIATIONS IN THE NATURE OF THE PLATINUM-GROUP MINERALS IN A CROSS-SECTION THROUGH THE MERENSKY REEF AT IMPALA PLATINUM: IMPLICATIONS FOR THE MODE OF FORMATION OF THE REEF
}

\author{
HAZEL M. PRICHARD ${ }^{\S}$ \\ School of Earth, Ocean and Planetary Sciences, University of Cardiff, Main College, Cardiff CF10 3YE, U.K. \\ SARAH-JANE BARNES \\ Sciences de la Terre, Université du Québec, 555, boulevard de l'Université, Chicoutimi, Québec G7H 2B1, Canada
}

WOLFGANG D. MAIER

Department of Geology, University of Pretoria, Pretoria 0002, Republic of South Africa

Peter C. FISHER

School of Earth, Ocean and Planetary Sciences, University of Cardiff, Main College, Cardiff CF10 3YE, U.K.

\begin{abstract}
A study of the abundance, size, distribution and composition of platinum-group minerals in samples from a section of the Merensky Reef at Impala Platinum, on the farm Reinkoyalskraal, in the western Bushveld Complex, South Africa, has shown that melanorite, leuconorite and anorthosite contain a PGM assemblage that consists almost exclusively of Pt and Pd bismuthotellurides, predominantly moncheite and merenskyite. In the chromite-rich lithologies, this assemblage of $\mathrm{Pt}-\mathrm{Pd}-\mathrm{Bi}$ telluride PGM is joined by a Pt-Pd-Rh sulfide PGM assemblage of cooperite, braggite and an unnamed Cu-Pt-Rh sulfide, with laurite and rare Sn-bearing PGM. This additional assemblage tends to be Pd-poor. The PGM are rarely enclosed by chromite. All the PGM are predominantly associated with base-metal sulfides, either as euhedral PGM or laths forming an exsolution texture within the base-metal sulfides. Rhodium, present as the unnamed $\mathrm{Cu}-\mathrm{Pt}-\mathrm{Rh}$ sulfide, is associated with pyrrhotite and pentlandite. Throughout this section of the reef, the PGM are commonly located at the edge of base-metal sulfides adjacent to serpentine, chlorite and amphibole that form on the edges of silicate grains. In the chromite-poor samples, Pt-Pd-Bi tellurides and their associated base-metal sulfides are located commonly within silicates, including plagioclase and quartz. The chromite-bearing rocks in this section of the Merensky Reef are enriched in Os, Ir, Ru, Rh and Pt. We test three models for the formation of the PGM: coprecipitation of PGM and chromite, crystallization of PGM from a sulfide liquid, and redistribution of PGE and base metals by hydrous intercumulus fluid. The strong association of PGM with base-metal sulfides suggests that the PGE were collected by an immiscible base-metal sulfide liquid. This liquid crystallized as Mss, with Rh being concentrated in the Mss, and then as Iss. These exsolved to pyrrhotite, pentlandite and chalcopyite and PGM. In the chromite-rich layer, we note a lack of minerals containing Pd in the PGM assemblage. No one model satisfactorily explains the PGM distribution. Rather, the PGM observed are likely to result from late, low-temperature processes superimposed on the magmatic ones.
\end{abstract}

Keywords: platinum-group minerals, Merensky Reef, Impala Platinum mine, chromitite, sulfide, telluride, Bushveld Complex, South Africa.

\section{SOMMAIRE}

Notre étude de l'abondance, la taille, la distribution et la composition des minéraux du groupe du platine (MGP) dans les échantillons prélevés d'une section du banc de Merensky à la mine Impala Platinum, sur la ferme Reinkoyalskraal, dans la partie occidentale du complexe de Bushveld, en Afrique du Sud, démontre que la mélanorite, la leuconorite et l'anorthosite contiennent un assemblage de MGP fait presqu'exclusivement de bismuthotellurures de Pt et Pd, surtout monchéite et merenskyite. Dans les

$\S \quad$ E-mail address: prichard@ cardiff.ac.uk 
roches riches en chromite, un assemblage de sulfures de Pt-Pd-Rh, soit cooperite, braggite et un sulfure à Cu-Pt-Rh sans nom, avec laurite et de rares MGP stannifères, viennent s'ajouter aux bismuthotellurures. Ce deuxième assemblage tend à contenir très peu de Pd. Les MGP sont rarement inclus dans la chromite. Tous les MGP sont surtout associés aux sulfures des métaux de base, soit sous forme de cristaux idiomorphes ou bien de lamelles d'exsolution dans ces sulfures. Le rhodium, par sa présence dans le sulfure à $\mathrm{Cu}-\mathrm{Pt}-\mathrm{Rh}$ sans nom, est associé à la pyrrhotite et la pentlandite. De part et d'autre de cette section du banc, les MGP sont généralement situés en bordure des sulfures des métaux de base, avoisinant la serpentine, la chlorite et l'amphibole qui forment les parties externes des grains de silicate. Dans les échantillons à faible teneur en chromite, les tellurures de Pt-Pd-Bi et les sulfures des métaux de base associés sont inclus dans les silicates, y inclus le plagioclase et le quartz. Les roches de cette section du banc de Merensky contenant la chromite sont enrichies en Os, Ir, Ru, Rh et Pt. Nous évaluons trois modèles de formation des MGP: coprécipitation des MGP avec la chromite, cristallisation des MGP à partir d'un liquide sulfuré, et redistribution des MGP et des métaux de base par l'intermédiaire d'une phase fluide intercumulus. L'association marquée des MGP avec les sulfures des métaux de base nous fait penser que les éléments du groupe du platine ont d'abord été concentrés dans un liquide sulfuré immiscible. Ce liquide a cristallisé sous forme de Mss, avec le Rh concentré dans la phase Mss, et ensuite sous forme de Iss. Ces minéraux ont par la suite exsolvé la pyrrhotite, la pentlandite, la chalcopyrite et les MGP. Dans le niveau enrichi en chromite, nous soulignons l'absence de minéraux contenant le Pd, parmi les MGP. Aucun des trois modèles explique avec satisfaction la distribution des MGP. A notre avis, les MGP résulteraient plutôt de processus tardifs, surimposés à basse température aux produits des processus magmatiques.

(Traduit par la Rédaction)

Mots-clés: minéraux du groupe du platine, banc de Merensky, mine Impala Platinum, chromitite, sulfure, tellurure, complexe de Bushveld, Afrique du Sud.

\section{INTRODUCTION}

The Bushveld Complex is a major source of the world's platinum-group element (PGE) supplies, the majority of which are hosted in the Merensky Reef and underlying UG2 chromitite (Vermaak 1976, Cawthorn et al. 2002a). The Merensky Reef is a mining term used to refer to the zone where the exploitable PGE grades occur (Vermaak 1976, Viljoen \& Schurmann 1998). The predominant rock-type is referred to as a "pegmatoidal feldspathic pyroxenite" (Lee 1996), although according to IUGS definitions, this is a coarse-grained to pegmatitic melanorite (Barnes \& Maier 2002). The pegmatite is bound by chromite layers (Vermaak \& Hendricks 1976), but PGE-rich sulfides may also be found up to several tens of $\mathrm{cm}$ below the basal chromitite. Both the silicate rocks and the chromite layers contain a small amount $(0.5$ to $3 \%)$ of base-metal sulfides (pyrrhotite, pentlandite and chalcopyrite). This definition refers to "normal" reef, whereas "pothole" reef occurs where the reef transgresses the floor and may come to rest several tens of meters below its normal level (Kinloch \& Peyerl 1990, Viljoen \& Schurmann 1998).

\section{PGM in the MEREnSKy ReEF}

There have been many studies of platinum-group minerals (PGM) in the Bushveld complex, e.g., Cawthorn et al. (2002b), Merkle \& McKenzie (2002). The PGM assemblage is variable along strike of the Merensky Reef. Vermaak \& Hendricks (1976) noted that the precious metals are predominantly associated with base-metal sulfides, either as PGM or in solid solution within them. Kinloch \& Peyerl (1990) and others have observed that "normal" reef is characterized by the
Pt-Pd sulfides braggite and cooperite, with laurite $\left(\mathrm{RuS}_{2}\right)$ commonly associated with chromitite layers, whereas in "pothole" reef, the predominant PGM are $\mathrm{Pt}-\mathrm{Fe}$ alloys at the center and Pt-Pd tellurides at the edge of potholes. At some localities, arsenic zones surround potholes, giving rise to the presence of sperrylite (Kinloch 1982). According to Kinloch, the PGE are more abundant in solid solution within the base-metal sulfides where they occur in reef located close to magmatic feeder-zones for the Bushveld Complex, such as near Rustenburg, and they are more likely to form PGM in reef located further from these feeder zones.

\section{The Merensky Reef at Impala Platinum}

The samples described here were obtained from Impala Platinum, and they come from the Reinkoyalskraal farm, situated in the western Bushveld (Fig. 1) and are typical of "normal" Merensky Reef. Impala is located some distance from the nearest magmatic feeder zone near Rustenberg (Sharpe et al. 1981). Thus according to Kinloch \& Peyerl (1990), the PGE should be present in PGM rather than in solid solution in basemetal sulfides. Despite the many studies of PGM from the Merensky Reef, there have been few detailed studies of the variation of PGM across the reef at any one locality. The section of reef examined in this study was chosen because it has been the subject of a detailed petrological and geochemical study (Barnes \& Maier 2002), who found that the chromite-bearing rocks of the reef contain similar amounts of $\mathrm{Ni}, \mathrm{Cu}, \mathrm{S}, \mathrm{Au}$ and $\mathrm{Pd}$ as the silicate rocks, but that they contain 5 to 10 times more Os, Ir, Ru, Rh and Pt than the silicate rocks. We have undertaken this study of the PGM located in polished sections of the samples studied by Barnes \& Maier 
(2002) in the hope of placing constraints on how the PGE are concentrated in both the silicate and chromitebearing rocks of the Merensky Reef at Impala.

\section{Methods}

Eight of the original 24 samples from Barnes \& Maier (2002) were selected by composition so that each rock type present in the reef is represented. The location, modal mineralogy and results of partial whole-rock analyses are listed in Table 1 . The polished thin sections of the samples were systematically searched for PGM by scanning each section in the back-scattered electron mode of a Cambridge Instruments (now Leo) S360 scanning electron microscope (SEM) at a magnification of $100 \times$ and analyzing bright minerals observed to determine whether they are PGM. The polished section of sample 22 has two distinct portions, a 3 -cm-thick melanorite layer and a 1-cm-thick chromite layer. Thus for the purposes of the PGM study, sample 22 has been treated as two samples, 22a (melanorite) and 22b (chromite layer). Similarly, sample 25 has two zones, a 3 -cm-thick layer of anorthosite (25a) and a 1-cm layer of chromite (25b).

Quantitative analyses of the PGM were made using an Oxford Instruments INCA energy-dispersion (EDX) analyzer attached to the scanning electron microscope. Operating conditions for the quantitative analyses were: $20 \mathrm{kV}$, with a specimen calibration current of $\sim 1 \mathrm{nA}$ and a working distance of $25 \mathrm{~mm}$. A cobalt reference standard was regularly and frequently analyzed, in order to check for any drift in the analytical conditions. A comprehensive set of standards was obtained from Micro Analysis Consultants Ltd. (St Ives, Cambridgeshire)

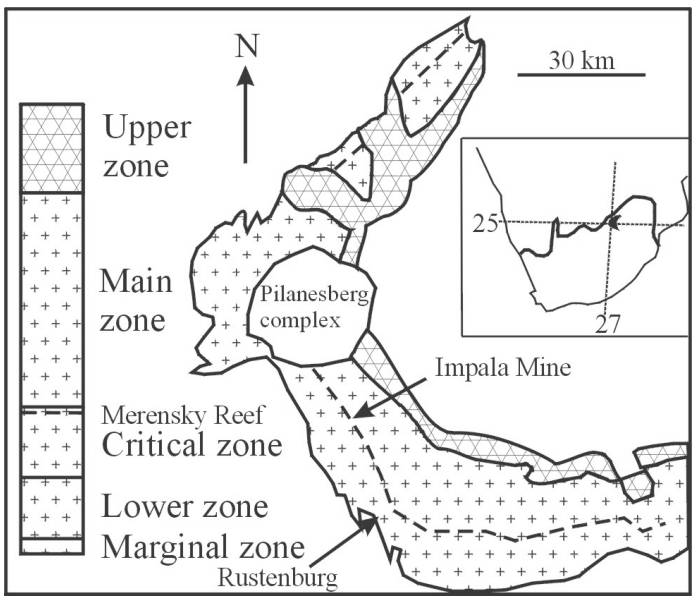

FIG. 1. Map of the western Bushveld Complex showing the location of Impala Platinum, from Barnes \& Maier (2002). and was used to calibrate the EDX analyzer. ZAF corrections were performed using the INCA software program. Images were obtained using a four-quadrant back-scattered detector operating at $20 \mathrm{kV}$, a beam current of $\sim 500 \mathrm{pA}$, and a working distance of $13 \mathrm{~mm}$, under which conditions magnifications up to $15000 \times$ are possible.

\section{Results}

Approximately 200 individual PGM were located and qualitatively identified (Table $2 \mathrm{a}$ and $2 \mathrm{~b}$ ). As has been reported previously from Impala (Mostert et al. 1982), PGE sulfides are the most common PGM present, accompanied by substantial amounts of Pt-Pd-Bi tellurides. Quantitative analyses of the PGM have been made for a small number of the PGM analyzed qualitatively (Table 3). In agreement with the whole-rock composition, there is a difference between the PGM of the chromite layers and those of the silicate rocks. The Pt$\mathrm{Pd}-\mathrm{Bi}$ tellurides are ubiquitous throughout the samples and are predominantly moncheite and merenskyite. In

TABLF 1. MODAI MINERALOGY AND WHOLE-ROCK COMPOSITION OF THE ROCKS FROM IMPALA PLATINUM

\begin{tabular}{|c|c|c|c|c|c|c|c|c|}
\hline Sample & 7 & 20 & 22 & 23 & 24 & 25 & 26 & 28 \\
\hline height $\mathrm{cm} \#$ & 78 & 13 & 6 & 3 & 0 & -3 & -8 & -23 \\
\hline length $\mathrm{cm}^{*}$ & 10 & 5 & 2 & 3 & 3 & 3 & 5 & 10 \\
\hline rock type & $\begin{array}{l}\text { mela } \\
\text { norit }\end{array}$ & mel & $\begin{array}{l}\text { - chro } \\
\text { te itit }\end{array}$ & $\begin{array}{l}\text { m- mela } \\
\text { e norit }\end{array}$ & $\begin{array}{l}\text { a- chron } \\
\text { te itite }\end{array}$ & & $\begin{array}{ll}\text { r- leuco } \\
\text { site norit }\end{array}$ & $\begin{array}{l}\text { o- leuco- } \\
\text { te norite }\end{array}$ \\
\hline \multicolumn{9}{|c|}{ Modal mineralogy } \\
\hline Chromite vol.\% & 1.0 & 1.0 & 20.0 & 5.0 & 40.0 & $<.5$ & $<.5$ & $<.5$ \\
\hline Orthopyroxene & 70.0 & 68.0 & 36.0 & 68.0 & 16.0 & 6.0 & 21.0 & 22.0 \\
\hline Clinopyroxene & 5.0 & 5.0 & 2.0 & 5.0 & 1.0 & 0.5 & 1.0 & 1.0 \\
\hline Plagioclase & 18.0 & 19.0 & 40.0 & 20.0 & 40.0 & 87.0 & 66.0 & 67.0 \\
\hline Sulfides $\left(p o, p n_{2}, \mathrm{cp}\right)$ & 1.1 & 3.0 & 0.8 & 1.5 & 1.0 & 1.0 & 4.5 & 2.2 \\
\hline Quartz & 2.0 & 1.0 & $<5$ & $<.5$ & $<.5$ & 1.0 & 2.0 & 2.6 \\
\hline Biotite & 1.5 & 1.0 & 1.0 & 0.5 & 1.6 & 2.0 & 1.6 & 1.3 \\
\hline Chlorite/Serpentine & 1.0 & 2.0 & $<.5$ & 0.5 & 0.0 & 2.0 & 4.0 & 3.5 \\
\hline \multicolumn{9}{|c|}{ Whole-Rock Compositions } \\
\hline$S w t \%$ & 0.45 & 1.2 & 0.3 & $4 \quad 0.6$ & $50 \quad 0.41$ & 0.4 & 1.83 & 0.97 \\
\hline $\mathrm{Cr}_{2} \mathrm{O}_{3}$ & 0.36 & 0.3 & $\begin{array}{ll}8 & 12.3\end{array}$ & $5 \quad 3.0$ & $13 \quad 22.31$ & 0.0 & 0.14 & 0.13 \\
\hline LOI & 0.34 & 0.4 & $5<0.1$ & 0.1 & $7<0.1$ & 0.7 & 1.16 & 0.89 \\
\hline Ag ppm & $<0.5$ & 1.4 & 0.6 & 0.5 & $<1.6$ & 0.3 & 1.4 & 0.5 \\
\hline As & $<0.5$ & $<0.5$ & $<0.5$ & $<0.5$ & $<0.5$ & $<0.5$ & $<0.5$ & $<0.5$ \\
\hline $\mathrm{Co}$ & 120 & 156 & 167 & 142 & 216 & 36 & 132 & 82 \\
\hline $\mathrm{Cu}$ & 793 & 2231 & 1215 & 936 & 887 & 691 & 2442 & 1318 \\
\hline $\mathrm{Ni}$ & 2300 & 5424 & 2130 & 3060 & 3400 & 1411 & 6448 & 3680 \\
\hline $\mathrm{sb}$ & $<0.02$ & 0.0 & $2<0.0$ & 40.0 & $12<0.0$ & $4 \quad 0.0$ & $03<0.02$ & $2<0.02$ \\
\hline $\mathrm{Se}$ & 1.6 & 4 & 1.5 & 2.1 & 1.3 & 1.3 & 6 & 3 \\
\hline Os ppb & 2.5 & 82 & 413 & 254 & 715 & 97 & 262 & 166 \\
\hline Ir & 3.9 & 31 & 552 & 308 & 1264 & 105 & 307 & 79 \\
\hline Ru & 27 & 116 & 2708 & 1692 & 6140 & 600 & 1752 & 1051 \\
\hline $\mathrm{Rh}$ & 4.6 & 89 & 1141 & 830 & 2665 & 286 & 770 & 394 \\
\hline $\mathrm{Pl}$ & 169 & 6418 & 22827 & 13369 & 37320 & 5126 & 18276 & 4302 \\
\hline $\mathrm{Pd}$ & 42 & 3064 & 2056 & 2807 & 4173 & 3025 & 9871 & 3032 \\
\hline $\mathrm{Au}$ & 235 & 1250 & 315 & 1076 & 339 & 389 & 2000 & 11.53 \\
\hline
\end{tabular}

\# Height relative to the basal chromite layer. ${ }^{*}$ Length of core for this sample. 
the chromite-bearing rocks, this assemblage is joined by $\mathrm{Pt} \pm \mathrm{Pd}$ sulfide, an unnamed $\mathrm{Cu}-\mathrm{Pt}-\mathrm{Rh}$ sulfide and laurite. Most of the PGM are associated with base-metal sulfides (Table $4 \mathrm{a}-\mathrm{c}$ ) and are commonly situated on the edges of these sulfides that are surrounded by silicate, in most cases plagioclase or alteration minerals

\begin{tabular}{|c|c|c|c|c|c|c|c|c|c|}
\hline Sample \# & $\begin{array}{c}\text { Pt } \\
\text { sulfide }\end{array}$ & $\begin{array}{l}\text { Pt-Pd } \\
\text { sulfide }\end{array}$ & $\begin{array}{l}\text { Pt-Rh- } \\
\text { Cu } \pm \text { Co } \\
\text { sullide }\end{array}$ & $\begin{array}{l}\mathrm{Pt}-\mathrm{Rh}- \\
\mathrm{Cu} \pm \mathrm{Co} \\
+\mathrm{Pd} \\
\text { sulfide }\end{array}$ & $\begin{array}{c}\mathrm{Ru} \\
\text { sulfide }\end{array}$ & $\begin{array}{c}\mathrm{Pt}-\mathrm{Te}- \\
\mathrm{Bi}\end{array}$ & $\begin{array}{l}\text { Pt-Pd- }- \text { Te-Bi } \\
\text { Te }\end{array}$ & $\begin{array}{c}\mathrm{Pd}-\mathrm{Tc}- \\
\mathrm{Bi} \\
\text { (no Pt) }\end{array}$ & $\begin{array}{l}\text { Other } \\
\text { PGM }\end{array}$ \\
\hline 7 & 2 & & & & & & 5 & & \\
\hline 20 & & & & & 1 & 2 & 2 & 3 & 1 \\
\hline $22 \mathrm{a}$ & 1 & 1 & & & & 4 & & & \\
\hline $22 b$ & 11 & 1 & & & 2 & 10 & 2 & & 3 \\
\hline 23 & 7 & & & & & 1 & l & & 2 \\
\hline 24 & 29 & 18 & 16 & 1 & 16 & 8 & 1 & & 3 \\
\hline $25 \mathrm{a}$ & & 4 & & & & 8 & & 1 & 2 \\
\hline $25 b$ & 1 & 2 & 1 & & 1 & & & & \\
\hline 26 & & I & & & & 11 & 5 & & 2 \\
\hline 28 & & & & & & 2 & 1 & & \\
\hline Total & 51 & 27 & 17 & 1 & 20 & 46 & 17 & 4 & 13 \\
\hline
\end{tabular}

TABLE 2b. SUMMARY OF GRAIN COUNT, EXPRESSED IN \%

\begin{tabular}{lcccr}
\hline Rock Type & Sulfides & Tellurides & Other & \# Grains \\
\hline All rock types & $59.2 \%$ & $34.2 \%$ & $6.6 \%$ & 196 \\
Chromite-bearing & 78.5 & 16.7 & 4.8 & 126 \\
Silicates & 24.3 & 65.7 & 10.0 & 70
\end{tabular}

including amphibole, chlorite and serpentine, which tend to form at the edge of the olivine and pyroxene grains. The sizes and host minerals to the PGM are shown in Table $4 \mathrm{a}$ and summarized in Tables $4 \mathrm{~b}$ and $4 \mathrm{c}$.

\section{PGM in the chromite-poor samples}

Silicate rocks as represented in the thin sections (melanorite 7, 20 and 22a, anorthosite 25a, leuconorite 26 and 28) host almost exclusively Pt-Pd-Bi tellurides, usually associated with base-metal sulfides. These samples are almost completely devoid of any grains of chromian spinel. Sample 23 (melanorite) also contains small clusters of chromite grains associated with the pyroxenes; in several cases, crystals of $\mathrm{Pt} \pm \mathrm{Pd}$ sulfide in this sample are close to these chromite grains. In the polished thin sections of these silicate samples, approximately three quarters of the PGM are in contact with base-metal sulfides, evenly distributed between chalcopyrite, pyrrhotite and pentlandite. In sample 26, the sulfides include euhedral pyrite in addition to chalcopyrite, pyrrhotite and pentlandite. This sample contains the most abundant pyrite, although a little pyrite occurs in other samples. Also in sample 26, occasional crystals of ruthenian pyrite occur within pyrite crystals. A quarter of the PGM are surrounded by silicates, including plagioclase, amphibole and serpentine. Also, these PGM may be surrounded by quartz interstitial to plagioclase, especially in the samples 26 and 28 taken from below the lower chromitite layer represented by sample 24 . Both the Pt-Pd-Bi tellurides in sample 28 are surrounded by quartz, and over a third of those in sample 26 are surrounded also by quartz (Fig. 2A). The basemetal sulfides in these cases are interstitial to the quartz.

TABLE 3. REPRESENTATIVE COMPOSITIONS (w\%) OF PGM FROM THI SFCTIONS STUDIED IN THIS CROSS-SECTION OF THE MERENSKY REEF

\begin{tabular}{|c|c|c|c|c|c|c|c|c|c|c|c|c|c|}
\hline Sample no. & ค. $S$ & $\mathrm{Fe}$ & $\mathrm{Co}$ & $\mathrm{Ni}$ & $\mathrm{Cu}$ & $\mathrm{Rh}$ & $\mathrm{Pt}$ & $\mathrm{Pd}$ & Ir & $\mathrm{Bi}$ & $\mathrm{Te}$ & As & Total \\
\hline 24 E 1 & 33.31 & 31.7 & 2.89 & 0.97 & 5.92 & 4.25 & 21.44 & & & & & & 100.49 \\
\hline $24 \mathrm{E} 12$ & 28.68 & 3.63 & 4.67 & 3.96 & 11.29 & 7.68 & 38.62 & & & & & & 98.53 \\
\hline 24 E 13 & 27.20 & 1.49 & 4.45 & 1.65 & 13.04 & 8.60 & 44.45 & & & & & & 100.88 \\
\hline 24 F 124 & 26.81 & 1.86 & 1.56 & & 12.45 & 13.88 & 42.28 & & 1.91 & & & & 100.75 \\
\hline $24 \mathrm{~F} 125$ & 15.87 & & & 2.29 & & & 74.66 & 7.68 & & & & & 100.50 \\
\hline $24 \mathrm{~F} 126$ & 22.65 & 0.70 & & 9.38 & & & 29.86 & 38.18 & & & & & 100.77 \\
\hline $24 \mathrm{~A} 27$ & 14.29 & & & & & & 83.66 & 1.71 & & & & & 99.66 \\
\hline $24 \mathrm{~J} 3 \quad 8$ & & 0.38 & & & 0.17 & & 3.13 & 24.18 & & 23.61 & 46.89 & 0.27 & 98.63 \\
\hline $22 \mathrm{G} 19$ & & & & & & & 40.02 & & & 16.27 & 42.38 & & 98.66 \\
\hline
\end{tabular}

$1\left(\mathrm{Pt}_{013} \mathrm{Rh}_{0.55} \mathrm{Cu}_{011} \mathrm{Fe}_{065} \mathrm{Co}_{00.05} \mathrm{Ni}_{0.02}\right)_{\Sigma 0.84} \mathrm{~S}$

$2\left(\mathrm{Pt}_{0.30} \mathrm{Rh}_{0.11} \mathrm{Cu}_{0.27} \mathrm{Fe}_{0.10} \mathrm{Co}_{0.12} \mathrm{Ni}_{0.10}\right)_{\Sigma 0.74} \mathrm{~S}$

$3\left(\mathrm{Pt}_{035} \mathrm{Rh}_{0.13} \mathrm{Cu}_{0.32} \mathrm{Fe}_{0,04} \mathrm{Co}_{0.12} \mathrm{Ni}_{0,04}\right)_{\Sigma 0.76} \mathrm{~S}$

$4\left(\mathrm{Pt}_{0.35} \mathrm{Rh}_{0.23} \mathrm{Cu}_{0.32} \mathrm{Fc}_{0.05} \mathrm{Co}_{0.04} \mathrm{Ir}_{0.02}\right)_{\Sigma 0.76} \mathrm{~S}$

$5\left(\mathrm{Pt}_{0.77} \mathrm{Pd}_{0.15} \mathrm{Ni}_{0.08}\right) \mathrm{S}$

$6\left(\mathrm{Pt}_{0.22} \mathrm{Pd}_{0.52} \mathrm{Ni}_{0.23} \mathrm{Fe}_{0.02}\right)_{\Sigma 0.97} \mathrm{~S}$

$7\left(\mathrm{Pt}_{0.96} \mathrm{Pd}_{0.04}\right) \mathrm{S}$

$8 \quad\left(\mathrm{Pd}_{0.90} \mathrm{Pt}_{0.06} \mathrm{Cu}_{0.01} \mathrm{Fe}_{0.03}\right)\left(\mathrm{Te}_{0.76} \mathrm{Bi}_{0.23} \mathrm{As}_{0.01}\right)_{\mathrm{\Sigma} 1.92}$

$9 \mathrm{Pt}\left(\mathrm{Te}_{0.81} \mathrm{Bi}_{0.18}\right)_{\Sigma 2}$
Compositions 1-3 of parts of (rh) in Fig. 2G

Composition of (rh) in Fig. $2 \mathrm{C}$ Composition of (pt) top left, bright rim, Fig. $2 \mathrm{C}$ Composition of (pt) top lcft, darker center, Fig. 2C Composition of (pt) in Fig. 2D Composition of (te) in Fig. 2B Composition of (te) in Fig. $2 \mathrm{H}$ 


\begin{tabular}{|c|c|c|c|c|c|c|c|c|c|c|c|c|c|c|c|c|c|}
\hline $\begin{array}{lr}\text { Sample } & N \\
\text { PGM type } & P C\end{array}$ & $\begin{array}{l}\text { No } \\
\text { PGM }\end{array}$ & $\begin{array}{l}\text { Ave. } \\
\text { size }\end{array}$ & $\begin{array}{l}\text { Largest } \\
\text { PGM }\end{array}$ & po & $\mathrm{pn}$ & $\mathrm{cp}$ & py & chr & $\mathrm{pl}$ & ol & $\mathrm{px}$ & $\operatorname{srp}$ & chl & amp & $q t z$ & $b t$ & C \\
\hline \multicolumn{18}{|l|}{7} \\
\hline PGMBiTe & 5 & $18 \times 4$ & $25 \times 5$ & & & 1 & & & & & & 1 & & 2 & 1 & 1 & \\
\hline $\begin{array}{l}\text { PGM sulfides } \\
20\end{array}$ & 2 & $7 \times 3$ & $8 \times 5$ & 1 & & & & & & 1 & & & & 1 & & & \\
\hline PGM BiTe & 7 & $21 \times 9$ & $52 \times 25$ & 2 & 3 & & & & & & & 5 & & 1 & & 1 & \\
\hline Laurite & 1 & $7 \times 7$ & & & 1 & & & & & & & 1 & & & & & 1 \\
\hline $\begin{array}{l}\text { Platarsite } \\
22 \mathrm{a}\end{array}$ & 1 & $10 \times 5$ & & l & 1 & & & & & & & l & & & & & 1 \\
\hline PGMBiTe & 4 & $65 \times 6$ & $200 \times 8$ & 1 & 1 & 3 & 1 & & 1 & & & 2 & 1 & & 1 & & \\
\hline $\begin{array}{l}\text { PGM sulfides } \\
22 b\end{array}$ & 2 & $6 \times 3$ & & & & 2 & & & 1 & & & & & & & & \\
\hline PGMBiTe $\quad 1$ & 12 & $9 \times 3$ & $31 \times 4$ & 1 & 3 & 3 & & & 4 & & & 1 & 3 & 2 & & & 2 \\
\hline PGM sulfides 1 & 12 & $8 \times 4$ & $14 \times 5$ & & 6 & 4 & & 1 & 8 & & & & 1 & & & 1 & \\
\hline Laurite & 2 & $5 \times 3$ & $7 \times 6$ & & & 1 & & & 1 & & & 2 & & & & & 1 \\
\hline Pt-Pd-Sn & 1 & $9 \times 5$ & & & 1 & & & & & & & 1 & 1 & & & & 1 \\
\hline $\begin{array}{l}\text { PtAsS } \\
23\end{array}$ & 1 & $10 \times 3$ & & & & 1 & & & & & & 1 & & & & & 1 \\
\hline PGMBiTe & 2 & $5 \times 4$ & $7 \times 6$ & & 1 & & & & 2 & & & & & & & & \\
\hline PGM sulfides & 7 & $6 \times 3$ & $12 \times 4$ & & 3 & 3 & & & 4 & & & 2 & & & & & \\
\hline $\begin{array}{l}\text { Pt-Pd-Sn } \\
24\end{array}$ & 1 & $4 \times 3$ & & & & 1 & & & 1 & & & & & & & & \\
\hline PGMBiTe & 9 & $7 \times 4$ & $27 \times 18$ & 3 & 1 & 4 & & 3 & 3 & 1 & 1 & 3 & 1 & 1 & & & 3 \\
\hline PGM sulfides 4 & 47 & $18 \times 8$ & $\mathrm{I} 12 \times 12$ & 9 & 19 & 25 & 1 & 11 & 13 & 1 & 2 & 6 & 9 & 3 & 2 & 1 & 7 \\
\hline Cu-Pt-Rh sulf 1 & 17 & $33 \times 10$ & $86 \times 45$ & 7 & 9 & 4 & l & 2 & 3 & & & 3 & & 5 & 1 & & 1 \\
\hline Laurite & 16 & $12 \times 6$ & $54 \times 18$ & 4 & 4 & 9 & 1 & 3 & 2 & & & 1 & 2 & 1 & & 1 & 4 \\
\hline RhAsS & 1 & $3 \times 1$ & & & & & & 1 & & & & 1 & & & & & 1 \\
\hline IrRhAsS & 1 & $3 \times 1$ & & & 4 & & & & & & & & & & & & 1 \\
\hline $\begin{array}{l}\text { Pt-Pd-Sn } \\
25 \mathrm{a}\end{array}$ & 1 & $5 \times 3$ & & & & & & & & & 1 & & & & & & 1 \\
\hline PGMBiTe & 9 & $14 \times 4$ & $25 \times 9$ & 4 & 3 & 2 & & & 9 & & & 1 & & & & & 2 \\
\hline PGM sulfides & 4 & $42 \times 14$ & $80 \times 37$ & 2 & 2 & 4 & & & 2 & & & & 3 & & & & 2 \\
\hline $\begin{array}{l}\text { Pt-Sn-S } \\
25 b\end{array}$ & 2 & $8 \times 3$ & $13 \times 4$ & 1 & & 1 & & & 2 & & & & & & & & 1 \\
\hline PGM sulfides & 3 & $15 \times 6$ & $30 \times 10$ & & 3 & & & & 3 & & & & & & & & \\
\hline Cu-Pt-Rh sulf & 1 & $1 \times 1$ & & & 1 & & & & & & & & & & & & 1 \\
\hline $\begin{array}{l}\text { Lauritc } \\
26\end{array}$ & 1 & $4 \times 3$ & & 1 & & 1 & & & 1 & & & & & & & & 1 \\
\hline PGMBiTe & 16 & $32 \times 6$ & $122 \times 8$ & 3 & 4 & 3 & 4 & & 7 & & & & & & 5 & & \\
\hline PGM sulfide & 1 & $19 \times 7$ & & 1 & & & & & & & & & & & & & \\
\hline $\begin{array}{l}\mathrm{Pd}-\mathrm{Hg}-\mathrm{Te} \\
28\end{array}$ & 1 & $6 \times 4$ & & & & & & & 1 & & & & & & 1 & & l \\
\hline PGMBiTe & 3 & $40 \times 6$ & $100 \times 15$ & 1 & 1 & & & & 2 & & & & & & 3 & & \\
\hline
\end{tabular}

PGMBiTe represent Pt-Pd-Bi tellurides, PGM sulfides represent Pt-Pd-S and Pt-S, laurite $\left(\mathrm{RuS}_{2}\right)$ and others. Average sizes in micrometers, largest sizes in micrometers and host minerals to PGM are given for each category. Note: a PGM may have more than one host if it is situated at the contact of two or more minerals. Hosts are: po pyrrhotite, pn pentlandite, cp chalcopyrite, py pyrite, chr chromite, pl plagioclase, ol olivine, px pyroxene, srp serpentinc, chl chlorite, amp amphibole, qtz quartz, bt biotite, C part of a composite PGM.

No PGM were observed associated with quartz in sections 20, 23 and 25, and only one in each of sections 7 and 22. In three cases, PGM are located in contact with biotite but not surrounded by it. The Pt-Pd-Bi tellurides are usually elongate, in some cases extremely so. They have a roundish outline where enclosed by base-metal sulfides or plagioclase, but most have a ragged outline where enclosed in quartz, serpentine and chlorite (Fig. 2B).
PGM in the chromite-bearing samples

The PGM in chromite-rich sample 24 also are associated with base-metal sulfides. Only very rarely are PGM totally or partially enclosed by chromite grains, and in these cases, the PGM are invariably surrounded by base-metal sulfides, either in a roundish inclusion (Fig. 2C) in or on the edge of chromite. A variety of PGM sulfides are present, including commonly $\mathrm{Pt} \pm \mathrm{Pd}$ sulfide, an unnamed $\mathrm{Cu}-\mathrm{Pt}-\mathrm{Rh}$ sulfide and laurite. 
The Pt sulfide (locally Pd-bearing) is generally equant, euhedral to subhedral, with sharply defined edges (Figs. 2D-F). Where enclosed within base-metal sulfides, it tends to be euhedral to subhedral, whereas in contact with silicates, it tends to have more irregular edges. It is almost always situated at the edge of basemetal sulfides, whether pyrrhotite, pentlandite or chalcopyrite. Only four out of the $47 \mathrm{Pt} \pm \mathrm{Pd}$ sulfide crystals identified in sample 24 are not in contact with basemetal sulfides. Two of the Pt-Pd sulfide crystals show $\mathrm{Pd}$ zoning. In one case, an irregular crystal of Pt-Pd sulfide $2 \mu \mathrm{m}$ wide and $100 \mu \mathrm{m}$ long curves around a chromite grain and is hosted within the adjacent plagioclase, but this is the exception, as most of the $\mathrm{Pt} \pm \mathrm{Pd}$ sulfide crystals are euhedral and partially or completely surrounded by base-metal sulfides. The hosts of the PGM sulfide crystals with their associated base-metal sulfides include plagioclase, olivine, pyroxene, serpentine, chlorite, amphibole and, in one case, biotite.

The unnamed $\mathrm{Cu}-\mathrm{Pt}-\mathrm{Rh}$ sulfide is restricted to chromite-bearing samples, and all but one are in sample 24 . They show two distinct textures, with textural varieties between these two end-members. At one extreme, they are lath-shaped or trapezium-shaped, with a euhedral outline and good cleavages where surrounded by base-metal sulfide, but like the $\mathrm{Pt} \pm \mathrm{Pd}$ sulfide crystals, many have irregular edges where they are in contact with silicates (Fig. 2G). At the other extreme, they are intergrown with their host base-metal sulfide, forming ragged patches (Fig. 2E) or needles with a subhedral outline (Fig. 2F), and they contain what seems to be an exsolution texture. PGM laths in some cases cross composite base-metal sulfide crystals (i.e., of more than one type), and a few extend or protrude into silicates, but they usually sit within the outline of the base-metal sul-

TABLE 4b. NUMBERS OF MINERALS IN CONTACT WITH THE SULFIDE. Pt AND Pd PGM EXPRESSED AS PERCENTAGES OF THE TOTAL OF PGM LOCATED IN THE SAMPLES STUDIED ACROSS THIS SECTION OF THE MERENSKY REEF

\begin{tabular}{lccccc}
\hline Rock Type & potpn+cp & chromite & $\mathrm{pl}+\mathrm{ol}+\mathrm{px}$ & $\mathrm{bt}+\mathrm{qtz}$. & $\mathrm{srp}+\mathrm{chl}+\mathrm{amp}$ \\
\hline All rock types & 54.3 & 7.1 & 19.3 & 2.5 & 16.8 \\
Chromite-bearing & 54.3 & 7.9 & 18.3 & 3.0 & 16.5 \\
Silicates & 54.6 & 3.0 & 24.2 & 0.0 & 18.2 \\
\hline
\end{tabular}

TABLE 4c. NUMBERS OF MINERALS IN CONTACT WITH THE Pt AND Pd BISMUTHOTELLLRIDE PGM, EXPRESSED AS PERCENTAGES OF THE TOTAL OF PGM LOCATED IN THE SAMPLES STUDIED ACROSS TIIS SECTION OF MERENSKY REEF

\begin{tabular}{lccccc}
\hline Rock Type & po+pn+cp & chromite & $\mathrm{pl}^{\mathrm{l}+\mathrm{o}\}+\mathrm{px}}$ & $\mathrm{bt+ \textrm {qt } z}$ & $\mathrm{stp}+\mathrm{chl}+\mathrm{amp}$ \\
\hline All rock types & 43.4 & 2.5 & 24.6 & 9.8 & 19.7 \\
Chromite-bcaring & 39.5 & 7.9 & 23.6 & 0.0 & 29.0 \\
Silicates & 45.2 & 0.0 & 25.0 & 14.3 & 15.5
\end{tabular}

fide. The Rh-rich PGM tend to be associated with pyrrhotite and pentlandite rather than chalcopyrite (Table 4a-c). The PGM sulfide containing Rh invariably also contains $\mathrm{Cu}$ and $\mathrm{Pt}, 50 \%$ contain $\mathrm{Co}$, some have $\mathrm{Ni}$, one contains Pd and two contain Ir (Table 3, compositions 1-4). This mineral appears to be related to the malanitecuprorhodosite family $\mathrm{Cu}(\mathrm{Pt}, \mathrm{Ir})_{2} \mathrm{~S}_{4}-\mathrm{Cu}(\mathrm{Rh})_{2} \mathrm{~S}_{4}$, and essentially is the unnamed mineral $\mathrm{Cu}(\mathrm{Pt}, \mathrm{Rh})_{2} \mathrm{~S}_{4}$.

Most of the laurite $\left(\mathrm{RuS}_{2}\right)$ is located in sample 24, although one or two crystals also occur in the other chromite-bearing samples, $22 \mathrm{~b}$ and $25 \mathrm{~b}$, and one was found in a non-chromite-bearing sample (number 20, Table 2a). In sample 24, all 16 crystals of laurite are in close proximity to base-metal sulfides. In fact, all but two of the laurite crystals are in contact with base-metal sulfides, more commonly with chalcopyrite than pyrrhotite or pentlandite (Table $4 \mathrm{a}-\mathrm{c}$ ). One crystal of laurite is partially surrounded by chromite, two lie between chromite grains and are in contact with biotite. Most crystals of laurite are adjacent to PGM containing Pt (Fig. 2D), usually $\mathrm{Pt} \pm \mathrm{Pd}$ sulfide and, in a few cases, associated with Pt-Bi tellurides. The laurite crystals are usually subhedral; in one case, it is triangular, and in a second case, it is needle-shaped. Both these crystals are entirely enclosed within chalcopyrite, and recall an exsolution texture. One crystal of laurite, enclosed by pyrrhotite, forms around ruthenian pyrite.

$\mathrm{Pt}-\mathrm{Pd}-\mathrm{Bi}$ tellurides are relatively rare in sample 24 compared with the sulfide PGM. Two-thirds of the crystals of Pt-Pd telluride are surrounded by base-metal sulfides rather than silicates, and half of those in base-

FIG. 2. Scanning electron photomicrographs. A. Pt-Bi telluride enclosed in quartz. Sample 26. Scale bar represents $50 \mu \mathrm{m}$. B. Ragged Pd-(Pt-)Bi telluride in serpentine. Sample 24. Scale bar represents $20 \mu \mathrm{m}$. C. PGM in sulfides that are enclosed in chromite. The Pt-Pd sulfide contains variable amounts of $\mathrm{Ni}$. The $\mathrm{Cu}-\mathrm{Pt}-\mathrm{Rh}$ sulfide is also $\mathrm{Ir}-$ bearing. Sample 24. Scale bar represents $20 \mu \mathrm{m}$. D. Pt sulfide with laurite on the edge of chalcopyrite, sample 24. Scale bar represents $50 \mu \mathrm{m}$. E. A euhedral Pt-Pd sulfide located in base-metal sulfides and a $\mathrm{Cu}-\mathrm{Pt}-\mathrm{Rh}$ sulfide, which also is Ir-bearing, are intergrown with pentlandite. Sample 24. Scale bar represents $50 \mu \mathrm{m}$. F. Pt-Pd sulfide on the edge of base-metal sulfides with an attached lath of Pt$\mathrm{Rh}$ sulfide in the base-metal sulfides. Sample 24. Scale bar represents $20 \mu \mathrm{m}$. G. Euhedral $\mathrm{Cu}-\mathrm{Pt}-\mathrm{Rh}-\mathrm{Co}$ sulfide surrounded by pyrrhotite and pentlandite, with an irregular edge where the PGM is in contact with a silicate. Sample 24. Scale bar represents $20 \mu \mathrm{m}$. H. Elongate Pt-Bi telluride in base-metal sulfides, extending into silicates. Sample 22. Scale bar represents $100 \mu \mathrm{m}$. Key to symbols: te: Pt-PdBi telluride, ch: chromite, cpy: chalcopyrite, g: galena, l: laurite, ol: olivine, pt: Pt sulfide, pl: plagioclase, pn: pentlandite, po: pyrrhotite, $\mathrm{rh}$ : $\mathrm{Cu}-\mathrm{Pt}-\mathrm{Rh}$ sulfide, py: pyrite, qz: quartz, bi: biotite, s: serpentine. 

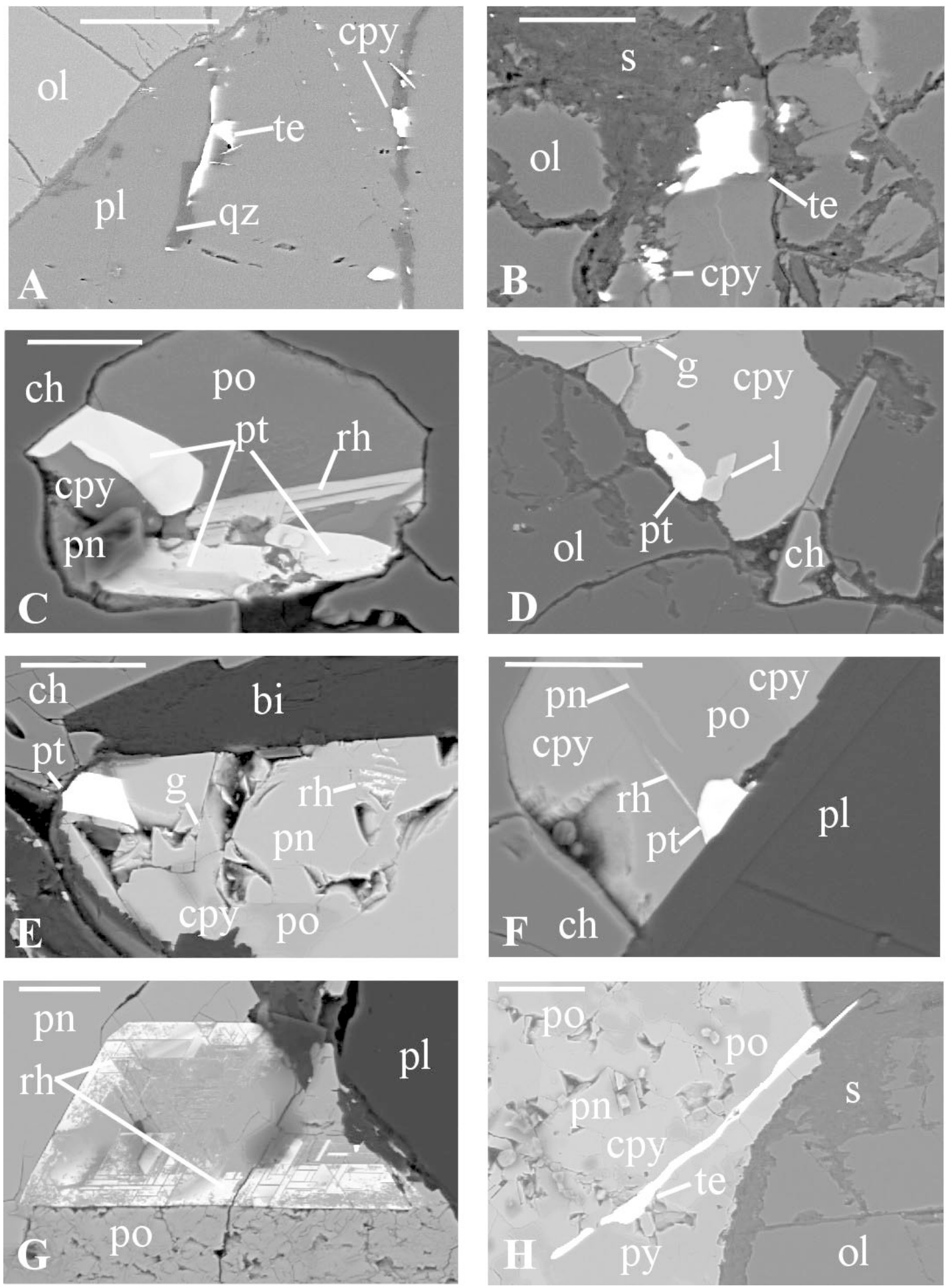
metal sulfides are associated with chalcopyrite. None are surrounded by chromite or quartz despite the presence of some interstitial quartz. A similar pattern of distribution is observed in the chromite-rich sample $22 \mathrm{~b}$, where Pt-Pd-Bi tellurides are in contact, in order of relative abundance, with chalcopyrite, pentlandite, pyrrhotite, serpentine and chlorite and one in quartz (Table 4a). The crystals of Pt-Pd-Bi telluride that are in contact with serpentine are spindly and ragged (Fig. 2H). The size of the crystals of Pt-Pd-Bi telluride is smaller in the samples from the chromitite layers than in the silicate rocks (Table 4a). Minerals containing Pd make up a smaller proportion of the total PGM in the chromite-rich sample 24 and in the other chromite-rich samples than in the silicate rocks.

\section{DISCUSSION}

The majority of the PGM in this section of the Merensky Reef at Impala consist of the sulfides of PGE ( $\mathrm{Pt} \pm \mathrm{Pd}$ sulfide, an unnamed $\mathrm{Cu}-\mathrm{Pt}-\mathrm{Rh}$ sulfide and laurite) and bismuth tellurides of PGE (moncheite and merenskyite). Throughout the Merensky Reef, the chromitite layers are the most enriched in PGE (Vermaak 1976), and this is true for the section of reef studied here (Barnes \& Maier 2002). In this study, we have shown that there is a distinctive difference in the PGM assemblage between the chromite-bearing and the silicate rocks. All of the rocks contain the bismuth telluride PGM. In addition, the chromite-bearing rocks contain $\mathrm{Pt} \pm \mathrm{Pd}$ sulfide, an unnamed $\mathrm{Cu}-\mathrm{Pt}-\mathrm{Rh}$ sulfide and laurite. These observations are in agreement with those of Mostert et al. (1982), who studied the PGM at Impala and also noted that the PGM are predominantly $\mathrm{Pt}-\mathrm{Pd}$ sulfide, Pt-Pd telluride and laurite. They also noted that the chromite-bearing rocks contain more laurite and cooperite than the silicate rocks.

Early investigators suggested that the position of the PGM at the edge of base-metal sulfides indicate that the PGM formed prior to base-metal sulfide crystallization and that either the PGM were trapped by the sulfide liquid and ejected to the edge of the sulfide liquid as it crystallized, or the PGM crystallized early attached to silicates and subsequently were surrounded by an interstitial sulfide liquid (Vernaak \& Hendricks 1976). It is clear from the mineralogical study presented here that indeed many of the PGM are associated with base-metal sulfides.

Barnes \& Maier (2002) showed that in results of whole-rock analyses of the samples collected from this section of reef, concentrations of $\mathrm{Pd}, \mathrm{Ni}, \mathrm{Cu}$ and $\mathrm{Au}$ correlate with the amount of $S$ throughout the reef. In the silicate rocks, the amounts of $\mathrm{Os}, \mathrm{Ir}, \mathrm{Ru}, \mathrm{Rh}$ and $\mathrm{Pt}$ also correlate with $\mathrm{S}$ content, but the chromite-bearing rocks contain 5 to 10 times more $\mathrm{Os}, \mathrm{Ir}, \mathrm{Ru}, \mathrm{Rh}$ and $\mathrm{Pt}$ than the silicate rocks, while still containing similar quantities of $\mathrm{S}, \mathrm{Cu}$ and $\mathrm{Pd}$ to those in the silicate rocks. In this mineralogical study, we have shown that the en- richment of Os, $\mathrm{Ir}, \mathrm{Ru}, \mathrm{Rh}$ and $\mathrm{Pt}$ relative to the other chalcophile elements $(\mathrm{Pd}, \mathrm{Cu}, \mathrm{Au})$ in the chromititebearing rocks is reflected in the PGM assemblage, which is dominated by $\mathrm{Pt}$ sulfide, an unnamed $\mathrm{Cu}-\mathrm{Pt}-\mathrm{Rh}$ sulfide and laurite.

Barnes \& Maier (2002) considered three possible models for the origin of the enrichment in Os, Ir, $\mathrm{Ru}$, $\mathrm{Rh}$ and Pt in the chromite-bearing rocks: i) crystallization of PGM directly from the silicate magma, ii) collection of PGE by a base-metal sulfide liquid from the silicate magma, iii) redistribution of the PGE and basemetal sulfides by a hydrous fluid. The possible role of each of the processes is examined below in light of results of the mineralogical study presented here.

\section{Crystallization of PGM from the silicate magma}

It has been suggested the PGE enrichment observed in most chromitites of the Critical Zone occurs as a result of crystallization of PGM directly from the silicate magma (Hiemstra 1979, Lee \& \& Tredoux 1986, von Gruenewaldt et al. 1989, Merkle 1992, Scoon \& Teigler 1994). It has been demonstrated that laurite can crystallize directly from a silicate magma (Brenan \& Andrews 2001). In the chromite grains of the lower, middle and upper chromitites of the LG, MG and UG series, the PGM containing Os-, Ir- and Ru are often enclosed in the chromite grains (Maier et al. 1999, Merkle 1992), implying that these PGM formed directly from the silicate magma prior to chromite crystallization. However, the location of the PGM containing Os, Ir and Ru in this section of the Merensky Reef is quite different. These PGM are associated with base-metal sulfides and are not enclosed in chromite. This fact suggests a different mechanism of formation for these PGM in the Merensky Reef than for the underlying chromitites, which also needs to account for the excess in $\mathrm{Pt}$ and $\mathrm{Rh}$ in the chromite layers in this section of the Merensky Reef.

Based on recent experimental work, Borisov \& Palme (2000) calculated that if the magma is not saturated in sulfide liquid, then at conditions of the QFM buffer, primitive basaltic magmas should be saturated in $\mathrm{PtFe}, \mathrm{IrFe}$ and $\mathrm{RuFe}$ alloys, but not in $\mathrm{Pd}$ or $\mathrm{Au}$ (data for $\mathrm{Os}$ and $\mathrm{Rh}$ are not available). Thus $\mathrm{Pt}$, Ir and $\mathrm{Ru}$ could precipitate as PGM alloys. Therefore, it is possible that during the formation of the chromite-bearing rocks of the Merensky reef, the silicate magma became saturated with Fe-PGE alloys (Fig. 3A); these minerals could thus have accumulated on the pile of crystals (the proto-anorthosite), along with the chromite and orthopyroxene to form the chromite-bearing rocks of the reef (Fig. 3B). If this were the process by which the PGE-enrichment occurred in the chromite-rich rocks, the PGM present should be Fe-PGE alloys.

Alternatively, Barnes et al. (2001) summarized the effect of a reduction of pressure on PGE-bearing sulfide liquid as it rises from the mantle and is erupted in lavas. Wendtland (1982) and Mavrogenes \& O'Neill 
(1999) have shown that sulfur solubility in a magma is critically dependent on pressure. A loss of sulfur during ascent will cause the formation of $\mathrm{Pt}-\mathrm{Ir}$ and $\mathrm{Ru}-\mathrm{Os}$ alloys. These alloys then would settle by gravity onto the pile of crystals along with the chromite. Although these PGM would not form directly from the silicate magma, the result would also be the production of PGE alloys. The problem with this hypothesis is that the PGM are small, and this fact would make gravity settling problematic, although if achieved it would provide a process to produce the required excess of $\mathrm{Pt}, \mathrm{Ir}, \mathrm{Ru}$ and $\mathrm{Os}$.

Crystallization of PGM directly from the silicate magma has been questioned on the grounds that at the low levels (0.1-10 ppb) of PGE found in basaltic magmas, it is unlikely that the magma would be saturated in PGE. The presence of base-metal sulfides with the PGM in the Merensky Reef is inconsistent with direct crystallization of PGM because a base-metal sulfide liquid in equilibrium with a mafic magma at normal $f\left(\mathrm{O}_{2}\right)$, i.e., close to QFM, would dissolve all of the PGE (Andrews $\&$ Brenan 2002). Therefore according to this first model, during the formation of the chromite layers, the magma could not have been saturated in a base-metal sulfide liquid. However, if during the formation of the melanorite the magma became saturated in base-metal sulfide liquid, and this liquid collected most of the PGE that remained in the magma, then some of this PGEbearing sulfide liquid could have percolated downward through the pile of cumulates into the chromite layer, further enriching the PGE content (Fig. 3C).

In our study, we have shown that in the chromite layers, the PGM are not alloys but PGM sulfides or bismuthotellurides, present as exsolution lamellae from base-metal sulfides, although irregular grains of Pt-Fe alloy, surrounded by cooperite, have been described at Impala by Mostert et al. (1982). Therefore, either the PGM did not crystallize directly from the silicate magma or, as suggested by Andrews \& Brenan (2002), base-metal sulfides have been added after the crystallization of the PGM and have modified the PGM assemblage (Fig. 3D).

\section{Collection of PGE by a base-metal sulfide liquid}

Campbell et al. (1983) suggested that the PGE and chalcophile elements of the Merensky Reef were collected by base-metal sulfide liquid from the silicate magma and then settled onto the pile of cumulates. This model could be applied to our reef section as follows. Shortly after formation of the proto-anorthosite, chromite and orthopyroxene began to crystallize and accumulate in the magma to form a chromite and orthopyroxene-laden mush (Fig. 4A), i.e., the chromitebearing rocks of the reef. As the magma became Cr-depleted, chromite ceased to crystallize and orthopyroxene crystallized alone to form a crystal mush, the proto-melanorite (Fig. 4B). The overlying magma was saturated in base-metal sulfide liquid, which interacted
A) Crystallization of chromite and PGM

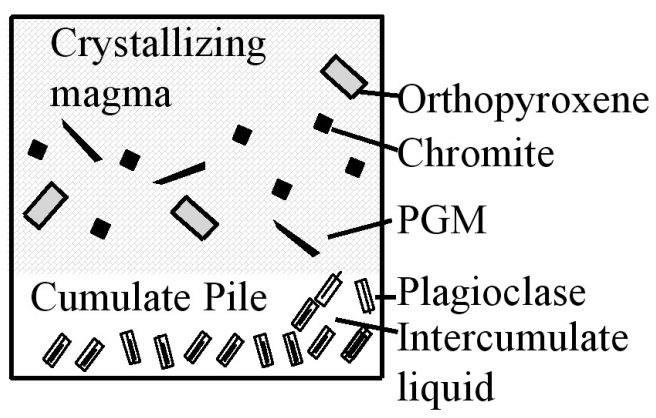

B) Collection of PGM and chromite on crystal pile

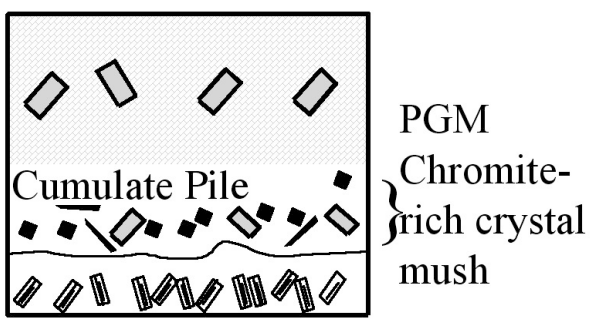

C) Base-metal sulfide liquid forms and percolates onto the cumulate pile

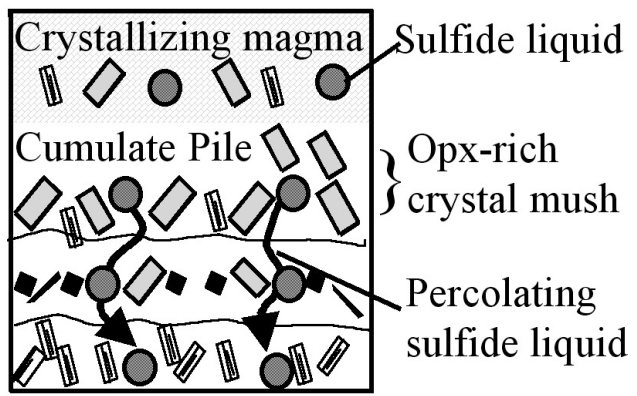

D) Sulfide liquid in the chromite layer dissolves laurite and Pt alloys.

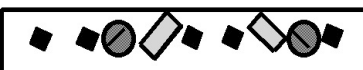

FIG. 3 (A-D). Sketches of the sequence of crystallization proposed for model 1, crystallization of PGM from the silicate magma. Opx: orthopyroxene. 
with a large volume of silicate magma to collect $\mathrm{Ni}, \mathrm{Cu}$, PGE, Bi, Te and other chalcophile elements. This sulfide liquid settled onto the pile of crystals to form the reef. In order to explain the presence of base-metal sulfides in the anorthosite layer, it is necessary to argue that the sulfide liquid percolated downward through the semiconsolidated pile of cumulates into the footwall anorthosite layer (Fig. 4B). Based on the presence of 30 to $40 \%$ oikocrysts in both rock types (Barnes \& Maier 2002), there was at least $40 \%$ intercumulate liquid present. The microstructures in the rocks show that piles of crystals underwent deformation during compaction, and that the sulfide liquid percolated downward along a vertical network of cracks. The sulfide liquid crystallized as Mss and Iss. At lower temperatures, the PGM we now observe exsolved from the Mss and Iss.

This model is consistent with the exsolution of PGM from the Iss and Mss and the close association of PGM with sulfides, but does not explain why the sulfide liq-

A) Crystallization of chromite and opx on cumulate pile to form chromite layer

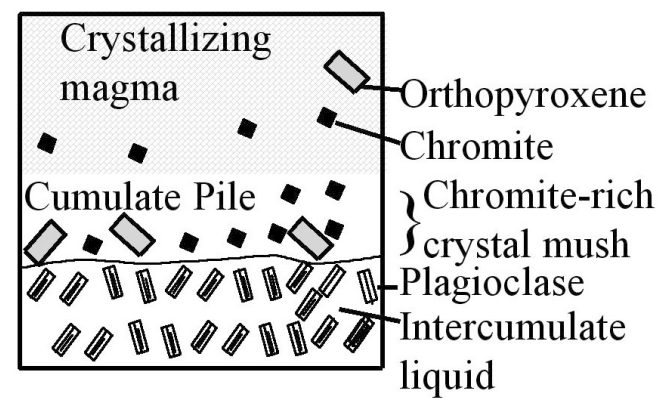

B) Magma becomes saturated in sulfide liquid, which percolates into the cumulate pile.

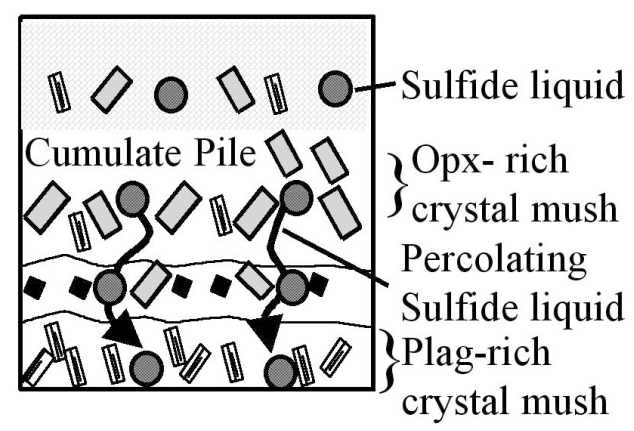

uid in the chromite-bearing rocks should contain 5 to 10 times more PGE than the sulfide liquid in the silicate rocks, and the consequent formation of sulfide PGM in the chromite-bearing rocks.

Barnes \& Maier (2002) also suggested that enrichment of sulfides in the chromite layers arose because of the crystallization of PGM from the sulfide liquid (rather than from the silicate liquid as described in model one). In this model, PGE and chalcophile elements are collected by a base-metal sulfide liquid. That fraction collects on the pile of cumulates, at the time of the formation of the melanorite, and percolates downward much in the manner described above (Figs. 4A, B). As the rocks cooled, the base-metal sulfide liquid in the chromite-bearing rocks lost $\mathrm{Fe}$ to the chromite (which was already solid), and $\mathrm{S}$ was released as a vapor (Fig. 4C). The idea that the sulfide liquid interacted with the solid chromite was suggested by the work of Naldrett \& Lehmann (1988), who argued that during cooling, $\mathrm{Fe}$

C) S and Fe are lost from the sulfide liquid in the chromite layer and PGM crystallize in the sulfide liquid

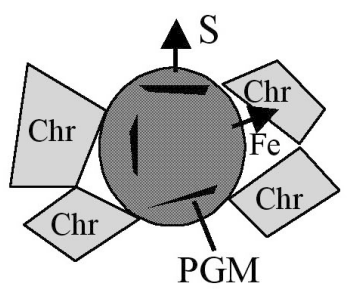

D) Compaction. Fractionated sulfide liquid escapes. Chromite grains anneal trapping some PGM and base-metal sulfides

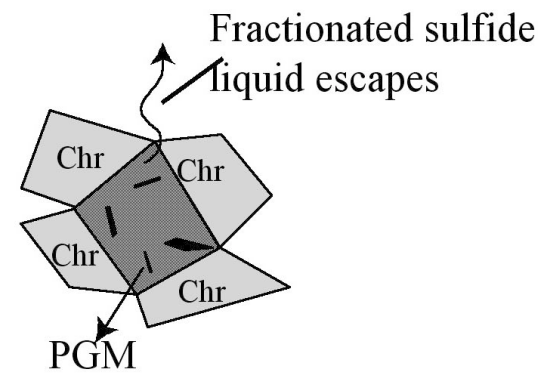

FIG. 4 (A-D). Sketches of the sequence of crystallization proposed for model 2, collection of PGE by a base-metal sulfide liquid. Opx: orthopyroxene. Plag: plagioclase. Chr: chromite. Dark grey circle in c) represents sulfide liquid. Dark grey area in d) represents base-metal sulfides. 
diffuses from sulfide into chromite to fill vacancies in the chromite. The loss of Fe and S lowered the $f\left(\mathrm{~S}_{2}\right)$ of the base-metal sulfide liquid, which caused laurite, cooperite and $\mathrm{CuRhS}$ to crystallize from it. Finally, during compaction, the fractionated $\mathrm{Cu}-\mathrm{Pd}$-enriched sulfide liquid was squeezed upward out of the cumulate pile into the overlying magma, leaving a Os-, Ir-, Ru-, Rh- and Pt-enriched sulfide in the chromitite (Fig. 4D).

Two weaknesses of this model can be pointed out. Firstly, the fact that the sulfides in the chromite-bearing rocks contain five to ten times more PGE than the sulfides in the silicate rocks requires the removal a fractionated sulfide liquid that is five to ten times the mass of the sulfides that remained in the chromite layer. The fractionated sulfide liquid must pass through the overlying melanorite without leaving a trace, since the sulfides in the melanorite overlying the chromite are not $\mathrm{Cu}-\mathrm{Pd}-\mathrm{rich}$. This is a less of a problem than it may at first seem to be because the amount of fractionated sulfide liquid is small compared with the total amount of sulfides present in the reef. This is because the chromitebearing rocks only make up a small proportion of the reef $(\sim 10 \%)$, and they contain a lower proportion of sulfides than the silicate-bearing rocks (1 versus $3 \%$ ). Further, it is also possible that the fractionated sulfide liquid was completely expelled from the reef and absorbed by the overlying magma. The rocks of the overlying Main Zone and Upper Zone have higher $\mathrm{Pd} / \mathrm{Pt}$ values than the initial magmas (Barnes et al. 2004).

A second objection to the model might be that although the decreasing Fe and S content of the sulfide liquid could cause the crystallization of PGM sulfides (Majzlan et al. 2002, Karup-Møller \& Makovicky 2002), there is no experimental work to indicate whether a base-metal sulfide liquid at 900 to $1000^{\circ} \mathrm{C}$ containing $\mathrm{Pt}$ and $\mathrm{Ru}$ at the concentrations observed in the Merensky sulfides ( 0.3 and $0.03 \mathrm{wt} \%$, respectively) would be saturated in laurite and Pt sulfide. Assuming that it is possible to saturate the base-metal sulfide liquid in PGM sulfide at the ppm level, then this mechanism is feasible. Some support for the model is lent by the composition of the Pt sulfide which, according to the phase diagram of Verryn \& Merkle (2002), reflects a crystallization temperature of $>1,000^{\circ} \mathrm{C}$. However, as most of the observed PGM have textures and compositions that formed at less than $600^{\circ} \mathrm{C}$ by exsolution (as proposed below), they do not provide evidence for or against crystallization of PGM from a sulfide liquid.

\section{Redistribution of PGE by fluids}

A number of lines of evidence have been presented to support the idea that fluids are important in the formation of the Merensky Reef. These are the coarsegrained nature of the reef (e.g., Nicholson \& Mathez 1991, Mathez et al. 1997), the REE-rich nature of the clinopyroxene in the reef (Mathez 1995), and the Cl- rich nature of the apatite associated with the reef (Boudreau et al. 1986).

In their discussion of how fluids affect the formation of reefs, Willmore et al. (2000) proposed a model that could be applied to our reef section. In one variant of their model, they proposed that the fractionated intercumulate liquid, from within the unconsolidated cumulate pile, became saturated with a hydrous $\mathrm{Cl}$-rich fluid. [At the level of the Merensky reef, Mathez (1999) calculated that there was a $1.8-\mathrm{km}$ pile of underlying unconsolidated cumulates, so this fluid could come from fairly deep within the pile]. The fluid rose through the pile of cumulates and either completely or partly dissolved any sulfides it encountered (Figs. 5A, B). In the cases where the fluid only partly dissolved the sulfides (removing $\mathrm{S}$ and base metals), the residual sulfides could potentially be very rich in PGE. The fluid would have continued to rise until it reached the level where the intercumulate silicate liquid or overlying magma was not saturated in fluid. It then dissolved in the intercumulate silicate liquid or overlying magma and the $\mathrm{S}$ and any base metals would precipitate either as the intercumulate sulfides or dissolve into the magma. These sulfides would be PGE-poor.

This model might explain the PGE-enriched nature of the sulfides in the chromite-bearing rocks. One might argue that these sulfides are residual, and that the fluid has dissolved 80 to $90 \%$ of the original base-metal sulfide and some Pd, leaving an Os-, Ir-, Ru-, Rh-, and Ptenriched fraction (the same loss of sulfide as required in the sulfide-collection model described above). However, it does not explain why the PGE enrichment is associated with the chromite. To explain this fact, one could use the model of Mathez et al. (1997) for the formation of the chromite-rich layers. In their opinion, the chromite-rich layers are formed by partial melting of a proto-melanorite, brought about by the introduction of a hydrous intercumulate fluid from below. This hydrous fluid dissolves into the intercumulate liquid of the pyroxene mush and causes the pyroxene to melt and release $\mathrm{Cr}$. The presence of $\mathrm{H}_{2} \mathrm{O}$ in the melt causes chromite rather than orthopyroxene to crystallize.

\section{Which model applies?}

If we combine the processes of collection of PGE and chalcophile elements by sulfide liquid from a silicate magma, accumulation of the sulfide liquid on a crustal mush of orthopyroxene and upward migration of an intercumulate hydrous fluid resulting in partial melting of the cumulate to form a chromite-rich layer, an overall model can be constructed. In the first step of the model, orthopyroxene and base-metal sulfide liquid accumulate on the semiconsolidated anorthosite as a pyroxene mush. Some of the sulfide liquid percolates down a few centimeters into the "anorthosite mush" and solidifies as Mss, and some crystallizes as Mss in the orthopyroxene layer (Fig. 5A). Lower in the pile of cu- 
mulates, intercumulate silicate liquid becomes saturated in hydrous fluid. This fluid rises until it reaches the bottom of the orthopyroxene-dominant mush. Here, it partially melts the orthopyroxene, and chromite crystallizes as described by Mathez et al. (1997). The fluid could

\section{A) Cumulate pile with disseminated sulfides}

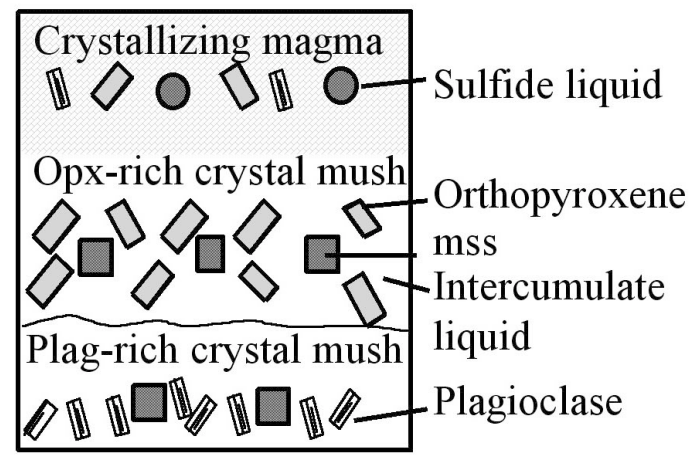

\section{B) Hydrous fluid exsolved from the intercumulate liquid and partially melts the lower part of the opx and mss crystal mush}

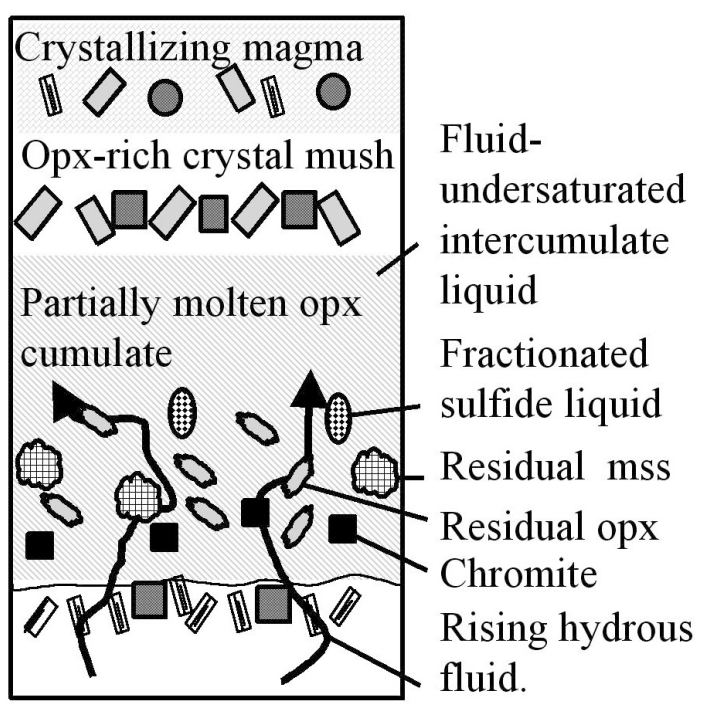

FIG. 5 (A-B). Sketches of the sequence of crystallization proposed for model 3, redistribution of PGE by fluids. also partially dissolve $\mathrm{S}$ in the Mss (Fig. 5B). Recent experiments (Peregoedova et al. 2002) show that if $\mathrm{S}$ is removed from $M s s$, it partially melts to form Fe-rich Mss, $\mathrm{Pt}$ alloy and $\mathrm{Cu}-\mathrm{Pd}$-bearing sulfide liquid. The $\mathrm{Cu}-$ Pd-bearing sulfide liquid and silicate partial melt from the base of the orthopyroxene layer were squeezed out of the chromite layer during compaction and dissolve in the overlying magma. Fe-rich Mss concentrates Os, Ir, $\mathrm{Ru}$ and $\mathrm{Rh}$ in preference to Pd (Barnes et al. 1997). The enrichment of $\mathrm{Os}, \mathrm{Ir}, \mathrm{Ru}$ and $\mathrm{Rh}$ and PGM containing these elements in the Mss of the chromite layers could thus be accounted for.

As outlined above, none of the models is entirely satisfactory. The strong association of the PGM with the base-metal sulfides, both in the chromite layers and in the rest of the reef, indicates that the PGM either formed early by direct crystallization from the magma and were surrounded by base-metal sulfides, or the PGE were incorporated into the sulfides, and the PGM then formed late by subsolidus exsolution from these base-metal sulfides.

The presence of pyrrhotite, pentlandite and chalcopyrite indicates that in both the silicate and chromite layers, the sulfide liquid crystallized as Mss and Iss. Also, in these samples, the PGM containing Rh tend to be enclosed by pyrrhotite and pentlandite, whereas $\mathrm{Pt} \pm$ $\mathrm{Pd}$ sulfide, $\mathrm{Pt}-\mathrm{Pd}-\mathrm{Bi}$ tellurides and laurite are more evenly distributed between $\mathrm{Ni}$-rich and $\mathrm{Cu}$-rich sulfides. Rhodium at least was concentrated into the Mss during its crystallization and the formation of a fractionated $\mathrm{Cu}$ rich liquid (Barnes et al. 1997). Thus in these samples, $\mathrm{Rh}$, and probably the other PGE, were concentrated within a sulfide liquid, and there is no remaining evidence that the PGM containing Rh crystallized prior to the crystallization of Mss. All three models allow for the PGE to be dissolved within an immiscible sulfide liquid at some point in the crystallization history, and all three have a mechanism to enhance the concentration of $\mathrm{Os}, \mathrm{Ir}, \mathrm{Ru}, \mathrm{Rh}$ and $\mathrm{Pt}$ within the chromite layers. Model one requires direct crystallization of PGM from the magma, enhancing the PGE concentration, possibly followed by the redissolution of the PGM into a PGEbearing sulfide liquid. Model two collects the PGE within an immiscible sulfide liquid and involves sulfide liquid and sulfur removal, enhancing the PGE concentration. Model three requires dissolution of sulfide and its removal, producing the consequent increase in PGE concentration.

\section{A secondary origin for the PGM}

This study was undertaken to identify the PGM, and so attempt to distinguish among these models. However, the PGM observed were probably formed at low temperatures, and the processes discussed in the three models took place at higher (magmatic) temperatures. If the PGM once were present as alloys, then they have been 
altered to the sulfides and bismuthotellurides observed in this study.

In many cases, the PGM appear to have exsolved from the base-metal sulfide. In both the silicate and chromite layers, the sulfide liquid crystallized Mss and Iss. The Mss and Iss exsolved at $<600^{\circ} \mathrm{C}$ to form pyrrhotite, pentlandite and chalcopyrite. The sulfide PGM and probably the bismuthotelluride PGM observed in this study could all have exsolved from the base-metal sulfides, because these minerals are only stable at $<600^{\circ} \mathrm{C}$ (Hoffman \& MacLean 1976). Experimental studies have shown that the PGM assemblage is likely to have formed by subsolidus re-equilibration of the base-metal sulfides, which expel PGE during cooling, giving rise to PGM (Makovicky et al. 1986, Ballhaus \& Ryan 1995, Ohnenstetter et al. 1999). This hypothesis of low-temperature exsolution is supported by the morphology of the PGM revealed by this study. Two generations of PGM formation seem indicated by two types of textural relationships between the PGM and their host base-metal sulfides. The less common texture is one of laths of PGM cross-cutting the sulfides and fine regular intergrowths with the base-metal sulfides, especially in the case of the PGM containing Rh. Euhedral crystals of PGM constitute the more common texture.

Cawthorn et al. (2002b) observed that although the PGE content of the Merensky Reef is relatively constant, the minerals that host the PGE vary considerably. In their opinion, this pattern indicates a uniform process of collection and a secondary evolution of the PGM, which varies according to conditions locally in the reef. This hypothesis is in agreement with the views of Brynard et al. (1976), who suggested that the Merensky Reef formed by gravity concentration, and was subsequently modified by hydrothermal alteration, which caused variations in PGM along the reef. This view is also consistent with the observation that at any one site in the Bushveld, the PGM assemblage in the Merensky Reef is similar to that in the underlying UG2 chromitites (Kinloch 1982). Thus the PGM observed are likely to be the result of local hydrothermal processes.

Our mineralogical study shows that the excess Os, $\mathrm{Ir}, \mathrm{Ru}, \mathrm{Rh}$ and $\mathrm{Pt}$ found in the chromite is located in PGM sulfides, which are much more abundant in the chromite layers than in the silicate-dominant layers. If the PGM represent low-temperature re-equilibrated assemblages, then the reason for the presence of $\mathrm{Pt} \pm \mathrm{Pd}$ sulfide only in the chromitites may be explained by $\mathrm{Fe}$ loss from the base-metal sulfides to the chromitites during re-equilibration. This process was proposed by Von Gruenewaldt et al. (1986) for the Bushveld complex and by Naldrett $\&$ Lehmann (1988) to explain the excess of $\mathrm{Cu}$ and $\mathrm{Ni}$ compared with $\mathrm{Fe}$ in the sulfide assemblages in chromitites compared with that expected in Mss and Iss. During the loss of Fe, the PGE held in solid solution in base-metal sulfides will be forced to form PGM sulfides. The loss of $\mathrm{Fe}$ from the sulfide into the chromite, accompanied by the release of $\mathrm{S}$, could occur over a range of temperatures, starting just prior to the crystallization of the sulfide liquid. Then as the temperature drops, subsolidus re-equilibration occurs to produce an Fe-enriched chromite (Naldrett \& Lehmann 1988). Therefore, Fe loss may have occurred both at a magmatic stage and at a subsolidus stage in the chromite layers.

\section{Conclusions}

We have shown that, in the Impala Platinum ores of the western Bushveld Complex, the $\mathrm{Cu}-\mathrm{Pt}-\mathrm{Rh}$ sulfides and laurite are predominantly restricted to the chromiterich layers, which contain $83 \%$ PGE sulfides and $17 \%$ PGE bismuthotellurides. In contrast, the chromite-poor layers contain $27 \%$ PGE sulfides and $73 \%$ PGE bismuthotellurides. Although the excess Pt, Rh, Os, Ir and $\mathrm{Ru}$ in the chromite-rich lithologies observed in the geochemical study by Barnes \& Maier (2002) is not explained by this mineralogical study, it is clearly accounted for by a distinct additional PGE sulfide assemblage of predominantly $\mathrm{Pt} \pm \mathrm{Pd}$ sulfide, an unnamed $\mathrm{Cu}-\mathrm{Pt}-\mathrm{Rh}$ sulfide and laurite.

The presence of PGM with base-metal sulfides rather than chromite suggests a strong association with the sulfides. These sulfides thus played an important role in the collection of the PGE. The close association of the PGM and base-metal sulfides suggests that by whatever process, the PGE are likely to have been dissolved in sulfide liquid at some point during the crystallization history and then, as the system cooled and the liquid crystallized, the PGE were expelled to form PGM. However, the lack of base-metal sulfide or the excess of PGE (except for Pd) in the chromitite layers of the Merensky Reef can be explained by several processes, and may be a result of a combination of these processes including the loss of a Pd-rich fractionated immiscible sulfide liquid, Fe and sulfur loss during cooling. The present mineralogy does not reflect the mineralogy at the point of crystallization, and the PGM observed were not formed from the primary magma.

\section{ACKNOWLEDGEMENTS}

The authors thank Impala Platinum for providing the sample material. We also thank Professor R. Grant Cawthorn and an anonymous referee for their constructive comments, guest Associate Editor William P. Meurer for handling the manuscript and Professor Robert F. Martin for his usual careful editing of the manuscript.

\section{REFERENCES}

ANDREWs, D.R.A. \& BRENAN, J.M. (2002): The solubility of ruthenium in sulfide liquid; implications for platinum group mineral stability and sulfide melt - silicate melt partitioning. Chem. Geol. 192, 163-181. 
Ballhaus, C. \& Ryan, C.G. (1995): Platinum-group elements in the Merensky Reef. I. PGE in solid solution in the basemetal sulfides and down temperature equilibration history of Merensky ores. Contrib. Mineral. Petrol. 122, 241-251.

BARnES, S.-J. \& MAIER, W.D. (2002): Platinum-group elements and microstructures of normal Merensky Reef from Impala Platinum mines, Bushveld complex. J. Petrol. 43, 103-128.

\& AsHWAL, L. (2004): The distribution of the platinum-group elements in the Main and Upper zones of the Bushveld Complex. Chem. Geol. (in press).

Makovicky, E., Karup-Møller, S., MaKovicky, M. \& Rose-Hanson, J. (1997): Partition coefficients for $\mathrm{Ni}, \mathrm{Cu}, \mathrm{Pd}, \mathrm{Pt}, \mathrm{Rh}$ and $\mathrm{Ir}$ between monosulfide solution and sulfide liquid and the implications for the formation of compositionally zoned $\mathrm{Ni}-\mathrm{Cu}$ sulfide bodies by fractional crystallization of sulfide liquid. Can. J. Earth Sci. 34, 366374.

VAn Achterbergh, E., Makovicky, E. \& Li, Chusi 2001): Proton microprobe results for the partitioning of platinum-group elements between monosulfide solid solution and sulfide liquid. S. Afr. J. Geol. 104, 275-286.

Borisov, A. \& PALME M.H. (2000): Solubility of noble metals in Fe-containing silicate melts as derived from experiments in Fe-free systems. Am. Mineral. 85, 1665-1673.

Boudreau, A.E., Mathez, E.A. \& McCallum, I.S. (1986): Halogen geochemistry of the Stillwater and Bushveld complexes: evidence for the transport of the platinum-group elements by Cl-rich fluids. J. Petrol. 27, 967-986.

BREnAN, J.M. \& ANDREws, D. (2001): High-temperature stability of laurite and Ru-Os-Ir alloy and their role in PGE fractionation in mafic magmas. Can. Mineral. 39, 341-360.

Brynard, H.J., DE Villiers, J.P.R. \& ViLJoEN, E.A. (1976): A mineralogical investigation of the Merensky Reef at the Western Platinum mine, near Marikana, South Africa. Econ. Geol. 71, 1299-1307.

Campbell, I.H., Naldrett, A.J. \& Barnes S.J. (1983): A model for the origin of the platinum rich sulfide horizons in the Bushveld and Stillwater complexes. J. Petrol. 24, 133-165.

Cawthorn, R.G., Lee, C.A., Schouwstra, R.P. \& MellowSHIP, P. (2002b): Relationship between PGE and PGM in the Bushveld Complex. Can. Mineral. 40, 311-328.

, Merkle, R.K.W. \& Viljoen, M.J. (2002a): Platinum-group element deposits in the Bushveld Complex, South Africa. In The Geology, Geochemistry, Mineralogy and Mineral Beneficiation of Platinum-Group Elements (L.J. Cabri, ed.). Can. Inst. Mining Metall. Petroleum, Spec. Vol. 54, 389-430.

Hiemstra, S.A. (1979): The role of collectors in the formation of the platinum deposits of the Bushveld Complex. Can. Mineral. 17, 469-482.
Hoffman, E. \& MacLean, W.H. (1976): Phase relations of michenerite and merenskyite in the $\mathrm{Pd}-\mathrm{Bi}-\mathrm{Te}$ system. Econ. Geol. 71, 1461-1468.

Karup-Møller, S. \& Makovicky, E. (2002): The system FeOs-S at 1180,1100 , and $900^{\circ}$ C. Can. Mineral. 40, 499507.

KINLOCH, E.D. (1982): Regional trends in the platinum-group mineralogy of the Critical Zone of the Bushveld Complex, South Africa. Econ. Geol. 85, 1328-1347.

\& Peyerl, W. (1990): Platinum-group minerals in various rock types of the Merensky Reef: genetic implications. Econ. Geol. 85, 537-555.

LEE, C.A. (1996): A review of mineralization in the Bushveld Complex and some other layered intrusions. In Layered Intrusions (R.G. Cawthorn, ed.). Elsevier, Amsterdam, The Netherlands (103-145).

\& Tredoux, M. (1986): Platinum-group element abundances in the Lower and the Lower Critical Zones of the Eastern Bushveld Complex. Econ. Geol. 81, $1087-$ 1095 .

Maier, W.D., Prichard, H.M., Barnes, S.-J. \& Fisher, P.C. (1999): Compositional variation of laurite at Union Section in the Western Bushveld Complex. S. Afr. J. Geol. 102, 286-292.

Majzlan, J., Makovicky, M., Makovicky, E. \& RoseHansen, J. (2002): The system Fe-Pt-S at $1100^{\circ} \mathrm{C}$. Can. Mineral. 40, 509-517.

Makovicky, M., Makovicky, E. \& Rose-Hansen, J. (1986): Experimental studies on the solubility and distribution of platinum-group elements in base-metal sulfides in platinum deposits. In Metallogeny of Basic and Ultrabasic Rocks (M.J. Gallagher, R.A. Ixer, C.R. Neary \& H.M. Prichard, eds.). Institute of Mining and Metallurgy, London, U.K. (415-425).

MATHEZ, E.A. (1995): Magmatic metasomatism and formation of the Merensky Reef, Bushveld complex. Contrib. Mineral. Petrol. 119, 277-286.

(1999): On factors controlling the concentrations of platinum-group elements in layered intrusions and chromitites. In Dynamic Processes in Magmatic Ore Deposits and Their Application in Mineral Exploration (R.R. Keays, ed.). Geol. Assoc. Can., Short Course Notes 13, 251-285.

Hunter, R.H. \& KinZler, R. (1997): Petrologic evolution of partially molten cumulus: the Atok section of the Bushveld Complex. Contrib. Mineral. Petrol. 129, 2034.

Mavrogenes, J.A. \& O'NeILl, H.ST. C. (1999): The relative effects of pressure, temperature and oxygen fugacity on the solubility of sulfide in mafic magmas. Geochem. Cosmochim. Acta 63, 1173-1180. 
MERKLE, R.K.W. (1992): Platinum-group minerals in the middle group of chromitite layers at Marikana, western Bushveld Complex; indications for collection mechanisms and postmagmatic modification. Can. J. Earth Sci. 29, 209221.

\& McKenzie, A.D. (2002): The mining and beneficiation of South African PGE ores - an overview. In The Geology, Geochemistry, Mineralogy and Mineral Beneficiation of Platinum-Group Elements (L.J Cabri, ed.). Can. Inst. Mining Metall. Petroleum, Spec. Vol. 54, 793811.

Mostert, A.B., Hofmeyr, P.K. \& Potgieter, G.A. (1982): The platinum-group mineralogy of the Merensky Reef at Impala Platinum mines, Bophuthatswana. Econ. Geol. 77, 1385-1394.

NALDRETT, A.J. \& LehmanN, J. (1988): Spinel non-stoichiometry as the explanation for $\mathrm{Ni}-, \mathrm{Cu}-$ and PGE enriched sulfides in chromitites. In The Geo-Platinum Symposium Volume (H.M. Prichard, P.J. Potts, J.F.W. Bowles \& S.J. Cribb, eds.). Elsevier, London, U.K. (93-103).

Nicholson, D.M. \& MATHEZ, E.A. (1991): Petrogenesis of the Merensky Reef in the Rustenburg section of the Bushveld Complex. Contrib. Mineral. Petrol. 107, 293-309.

Ohnenstetter, M., Johan, Z., Cocherie, A., Fouillac, A.M., Guerrot, C., Ohnenstetter, D., Chaussidon, M., Rouer, O., Makovicky, E., Makovicky, M., Rose-Hansen, J., Karup-Møller, S., Vaughan, D., Turner, G., Pattrick, R.A.D., GIZE, A.P., LyON, I. \& McDonALD, I. (1999): New exploration methods for Pt and Rh deposits poor in basemetal sulfides - NEXTPRIM. Trans. Inst. Mining Metall. B108, 119-150.

Peregoedova, A., Barnes, S.-J. \& Baker, D. (2002): The formation of Pt and Ir minerals in base-metal sulfides: effect of sulfur fugacity and composition. In $9^{\text {th }}$ Int. Platinum Symp., Extended Abstr. (A. Boudreau, ed.), 363-366.

Scoon, R.N. \& TeigleR, B. (1994): Platinum-group element mineralization in the Critical Zone of the Western Bushveld Complex. I. Sulfide poor chromitites below the UG2. Econ. Geol. 89, 1094-1121.
Sharpe, M.R., Bahat, D. \& Von Gruenewaldt, G. (1981): The concentric elliptical structure of feeder sites to the Bushveld Complex and the possible economic implications. Trans. Geol. Soc. S. Afr. 84, 239-244.

VERMAaK, C.F. (1976): The Merensky Reef - thoughts on its environment and genesis. Econ. Geol. 71, 1270-1298.

\& HENDRICKS, L.P. (1976): A review of the mineralogy of the Merensky Reef, with specific reference to new data on the precious metal mineralogy. Econ. Geol. 71, 1244-1269.

Verryn, S.M.C. \& Merkle, R.K.W. (2002): The system PtS$\mathrm{PdS}-\mathrm{NiS}$ between $1200^{\circ} \mathrm{C}$ and $700^{\circ} \mathrm{C}$. Can . Mineral. 40 , 571-584.

Viljoen, M.J. \& SchurmanN, L.W. (1998): Platinum-group metals. In the Mineral Resources of South Africa (M.G.C. Wilson \& C.R. Anhaeusser, eds.). Council for Geoscience, Pretoria, South Africa (532-568).

Von Gruenewaldt, G., Hatton, C.J., Merkle, R.K.W. \& GAIN, S.B. (1986): Platinum-group element chromitite associations in the Bushveld Complex. Econ. Geol. 81, $1067-$ 1079.

Hulbert, L.J. \& NALdRETT, A.J. (1989): Contrasting platinum-group element concentration patterns in cumulates of the Bushveld Complex. Mineral. Deposita 24 219-229.

WENDTLAND, R.F. (1982): Sulfide saturation of basalt and andesite melts. Am. Mineral. 67, 877-885.

Willmore, C.C., Boudreau, A.E. \& Kruger, J.F. (2000): The halogen geochemistry of the Bushveld Complex, Republic of South Africa; implications for chalcophile element distribution in the Lower and Critical zones. J. Petrol. 41 , 1517-1539.

Received December 8, 2002, revised manuscript accepted October 1, 2003 